\title{
Gastric immunolocalization and plasma profiles of acyl-ghrelin in fasted and fasted-refed prepuberal gilts
}

\author{
N Govoni, R De lasio ${ }^{1}$, C Cocco ${ }^{2}$, A Parmeggiani, G Galeati, \\ U Pagotto ${ }^{1}$, C Brancia ${ }^{2}$, M Spinaci, C Tamanini, R Pasquali ${ }^{1}$, \\ G-L Ferri ${ }^{2}$ and E Seren
}

Department of Veterinary Morphophysiology and Animal Production, University of Bologna, via Tolara di Sopra 50, 40064 Ozzano Emilia (BO), Italy

${ }^{1}$ Endocrinology Unit and Center for Applied Biomedical Research (CRBA), Sant' Orsola-Malpighi Hospital, 40100 Bologna (BO), Italy

${ }^{2}$ NEF-Laboratory, Department of Cytomorphology, University of Cagliari at Monserrato, 09042 Monserrato (CA), Italy

(Requests for offprints should be addressed to N Govoni; Email: ngovoni@vet.unibo.it)

\begin{abstract}
Ghrelin is a peripheral circulating hormone, mainly released from the stomach, which can stimulate food intake. We studied fed, fasted and fasted-refed prepuberal gilts in order to outline possible changes in gastric mucosal ghrelin cells and in plasma ghrelin profiles in reponse to food deprivation. Acyl-ghrelin-immunoreactive cells were numerous in oxyntic glands, less abundant in cardiac glands and least frequent in pyloric glands, with the addition of a minor population of labelled cells in the gastric pit mucosa. When fed and fasted animals were compared (72-h fast versus fed; $n=4$ each), no clear-cut differences were revealed in labelled cell numbers, nor in their staining intensity. An RIA for plasma porcine acyl-ghrelin ( $n-$ octanoylated at Ser-3), not recognizing des-acyl-ghrelin, was validated. Plasma acyl-ghrelin progressively increased
\end{abstract}

upon fasting (over 6, 12, 24 and $48 \mathrm{~h}$ ); ghrelin levels significantly $(P<0 \cdot 05)$ higher than those prefast were reached at $72 \mathrm{~h}$. After refeeding, plasma ghrelin was rapidly restored to basal values by $6 \mathrm{~h}$. In the same animals, plasma insulin was significantly reduced throughout the fasting period (6-72 h), while rapidly increasing after refeeding. Non-esterified fatty acid levels increased during fasting (12-72 h) and rapidly returned to low values after refeeding. In conclusion, the present study demonstrates that starvation and refeeding influence ghrelin plasma level in prepuberal gilts. The absence of detectable changes in ghrelin cells, as seen in immunohistochemistry, could be due to a large intracellular storage of potentially releasable acyl-ghrelin.

Journal of Endocrinology (2005) 186, 505-513

\section{Introduction}

Ghrelin was discovered as a peptide hormone that potently stimulates growth hormone release from the anterior pituitary, as demonstrated in rats (Kojima et al. 1999, Seoane et al. 2000), humans (Peino et al. 2000, Takaya et al. 2000) and pigs (Salfen et al. 2004). In addition, evidence from many species indicates that ghrelin exerts a variety of actions, affecting energy balance (Horvath et al. 2001), gastrointestinal motility and secretion (Masuda et al. 2000) and feeding behaviour (Wren et al. 2000). The central orexigenic effects of ghrelin are independent on growth hormone stimulation and appear to be mediated, at least in part, through activation of neuropeptide Y/agoutirelated peptide hypothalamic neurons (Horvath et al. 2001). Administration of exogenous ghrelin increases neuropeptide $\mathrm{Y}$ gene expression and blocks leptin-induced feeding reduction, thus implying a possible competitive interaction between ghrelin and leptin in feeding regulation (Nakazato et al. 2001).
Ghrelin is synthesized as a prohormone, which is then proteolytically processed to yield a 28 -amino acid peptide. A unique modification is imposed on the hormone during biosynthesis in the form of $n$-octanoic acid bound to the Ser-3 residue; this is required for biologic activity. Such acylation is thought to be critical for transport across the blood-brain barrier, receptor binding and overall bioactivity (Muccioli et al. 2001, Banks et al. 2002). The major site of ghrelin production is the stomach mucosa (Date et al. 2000, Tomasetto et al. 2000, Rindi et al. 2002), whereas lower amounts derive from small and large intestine, pancreas, kidney, immune system, placenta, pituitary, testis, ovary and hypothalamus (Casanueva and Dieguez 2002). With the possible exception of mouse (Tomasetto et al. 2000), ghrelin cells have been demonstrated to be independent from somatostatin (D), serotonin (enterochromaffin, or EC) and histamine (enterochromaffin-like, or ECL)-producing cells (Date et al. 2000, Rindi et al. 2002), and comprise P/D1-type cells in human, A-like cells in rat and $X$ cells in dog (Rindi et al. 2002). In all 
species, ghrelin cells have been consistently revealed to be closed-type endocrine cells, with no contacts with the lumen (Rindi et al. 2002), in keeping with the indirect mechanisms of stimulation of ghrelin secretion. Across the different areas of gastric mucosa, ghrelin cells are mainly located in the acid-secreting mucosa, between the neck and the base of oxyntic glands, fewer being found within glands of the pyloric mucosa (Rindi et al. 2004). Ghrelinimmunoreactive cells have been reported to be numerous from the neck to the base of oxyntic glands in various farm animals, and abundant in cardiac and pyloric glands in swine (Hayashida et al. 2001). Circulating ghrelin levels depend on acute and chronic changes in energy balance, fasting increasing and feeding decreasing its concentrations. Hayashida and colleagues (2001) demonstrated that plasma ghrelin levels in the cow are reduced $1 \mathrm{~h}$ after feeding and return to prefeeding levels within $4 \mathrm{~h}$. Also, in rat $48 \mathrm{~h}$ starvation resulted in increased plasma ghrelin (Wren et al. 2000). In food-deprived weanling pigs, Salfen and colleagues (2003) recently demonstrated a short-lived suppression of plasma ghrelin (at $12 \mathrm{~h}$ ), followed by an increase at 30-36 h.

On the basis of these observations, the aims of this study in prepubertal gilts were to study both distribution and possible changes of acyl-ghrelin-immunoreactive cells in the main areas of gastric mucosa, to validate an RIA for measurement of acyl-ghrelin in porcine plasma and to determine plasma acyl-ghrelin profiles during fasting and after refeeding.

\section{Materials and Methods}

\section{Animals and experimental design}

A total of 16 Large White prepuberal gilts, with an average weight of $102 \cdot 8 \pm 2 \cdot 21 \mathrm{~kg}$ (mean \pm S.E.M.) was used. The animals were housed in individual crates in a controlled building and exposed to a constant temperature $\left(22^{\circ} \mathrm{C}\right)$ and artificial photoperiod ( $12 \mathrm{~h}$ light $/ 12 \mathrm{~h}$ dark). Pigs were fed daily a corn/soybean meal ration (14\% crude protein, $2848 \mathrm{kcal} / \mathrm{kg}$ metabolizable energy) supplemented with vitamins and minerals, according to the National Research Council guidelines (National Research Council 1988), whereas water was freely available. Animals were housed and used according to EEC animal-care guidelines; the experimental design and procedures had previously been submitted and approved by the Ethical Committee of Bologna University.

\section{Experiment 1: tissues for immunohistochemistry}

In order to immunolocalize the cellular distribution of ghrelin peptide within the stomach, eight gilts were slaughtered under different feeding conditions $(n=4$, normal alimentation; $n=4,72-\mathrm{h}$ fasting). For each animal, approximately $5 \times 5 \mathrm{~cm}$ samples of gastric wall were taken immediately after death from the oxyntic, cardiac and pyloric regions, from either the anterior or the posterior gastric wall. The mucosa was rapidly separated from the remainder of the wall with a scalpel, delicately stretched onto filter paper (luminal side up), briefly left to adhere, immersion-fixed in paraformaldehyde $(40 \mathrm{~g} / 1$ in $0 \cdot 1 \mathrm{M}$ phosphate buffer) for $3 \mathrm{~h}$ and rinsed in PBS $\left(10 \mathrm{mM} \mathrm{PO}_{4}\right.$, $\mathrm{pH} 7 \cdot 2-7 \cdot 4 / 150 \mathrm{mM} \mathrm{NaCl}$ ) containing $70 \mathrm{~g} / 1$ sucrose and $0 \cdot 2 \mathrm{~g} / 1 \mathrm{NaN}_{3}(12-36 \mathrm{~h})$. For each area, several (three or four) samples of mucosa were cut and used to compose at least three mixed blocks encompassing the three gastric areas mentioned per each animal. Tissues were then dipped in 'fluid' cryoembedding medium, oriented in aluminum foil moulds in 'dense' cryoembedding medium (fluid medium, $110 \mathrm{~g} / 1$ polyvinyl alcohol 6-98, $10 \mathrm{~g} / 1$ Tween-20, and $0.5 \mathrm{~g} / 1 \mathrm{NaN}_{3}$; dense medium, $65 \mathrm{~g} / 1$ polyvinyl alcohol 56-98, 42.6 g/l polyethylene glycol 400, $10 \mathrm{~g} / 1 \mathrm{Tween}-20$, and $0.5 \mathrm{~g} / 1 \mathrm{NaN}_{3}$; Cocco et al. 2003), snap-frozen in melting freon cooled with liquid nitrogen, and stored in the vapour phase of a liquid nitrogen tank. Sections were obtained using a cold-knife Microm HM560 cryomicrotome (Ferri et al. 2002) at a thickness setting of 5 or $10 \mu \mathrm{m}$, collected onto poly-L-lysine treated slides, air-dried, wrapped in aluminium foil and stored in a tank of liquid nitrogen until use.

\section{Experiment 2: plasma sampling}

Eight animals were fitted with an indwelling jugular catheter (Vygon, Ecouen, France) under general anaesthesia with thiopental sodium $(15 \mathrm{mg} / \mathrm{kg}$; pentothal sodium; Gellini, Latina, Italy); catheters were rinsed daily with physiological saline containing sodium heparin (190 IU/ ml; Eparina Vister, Pfizer, Latina, Italy) and antibiotics. After 2 days, the gilts were completely deprived of food for $72 \mathrm{~h}$ and then refed with the same diet given during the prefast period; water was available ad libitum. At the end of the fasting period all gilts were weighed again. Blood samples were withdrawn 12 and $6 \mathrm{~h}$ prior to the start of the fasting period $(-12 \mathrm{~h},-6 \mathrm{~h})$ and at $6,12,24,48$ and $72 \mathrm{~h}$ during fasting; animals were then bled 6, 12, 24 and $48 \mathrm{~h}$ after refeeding. In the prefast and refeeding periods meals were given after blood-sample collection. Blood samples were drawn into chilled polypropylene tubes containing sodium EDTA $(1.8 \mathrm{mg} / \mathrm{ml})$ and aprotinin $(500 \mathrm{U} / \mathrm{ml}$ blood kallikrein inactivator; Sigma-Aldrich, St Louis, MO, USA). After immediate centrifugation $\left(3000 \mathrm{~g}\right.$ ) for $10 \mathrm{~min}$ at $4{ }^{\circ} \mathrm{C}$, plasma was stored at $-80{ }^{\circ} \mathrm{C}$ until assayed for ghrelin, insulin, glucose and nonesterified fatty acids (NEFAs).

\section{Immunohistochemistry}

For each immunostaining session, comparable numbers of tissue sections from fed and fasted animals were treated in 
parallel. Slides were brought to room temperature, treated with Triton X-100 $(0 \cdot 1 \%$ in water; $1 \mathrm{~h})$, and incubated overnight with the primary antiserum (at room temperature, in a humid chamber). The secondary incubation was carried out using Cy3-conjugated, affinity-purified antirabbit secondary antibodies (Jackson Immunoresearch Laboratories, West Grove, PA, USA). After mounting with PBS/glycerol, slides were observed using an Olympus BX60 fluorescence microscope, equipped with a PM30 photographic system (Olympus, Milan, Italy) and a Fuji FinePix S2 PRO (Fujifilm, Milan, Italy) digital camera. A rabbit antiserum raised to the rat ghrelin ${ }_{1-11}$ peptide (kindly provided by $\operatorname{Dr}$ M Kojima) was used at 1:(10000-200 000) dilutions. Pre-absorption control experiments were carried out using the homologous $\mathrm{N}$ terminal acyl-ghrelin ${ }_{1-10}$ synthetic peptide (octanoylated at Ser-3), as well as the corresponding non-octanoylated peptide, up to approximately $30 \mu \mathrm{M}$. Routine immunostaining controls included substitution of each layer, in turn, with PBS. Sets of immunostained preparations, containing two/three sections each from a fed and a fasted animal, were assessed by two independent observers in a blind fashion, each main gastric mucosal area (cardiac, oxyntic, and piloric) being compared across each set. In order to address the possible 'degranulation' of a restricted subpopulation of ghrelin cells, as well as overall changes in cellular ghrelin content, each preparation was assessed for: labelled cell frequency, overall cell-labelling intensity and the spectrum of cell-labelling intensities; that is, the proportion of brightly compared with weakly immunostained cells.

\section{Ghrelin assay}

Ghrelin concentrations in plasma were measured by RIA, after solid-phase extraction, using a commercial rabbit anti-human ghrelin antibody (T-4745; Peninsula Laboratories, San Carlos, CA, USA). To estabilish the specificity of the T-4745 antiserum against octanoyl-ghrelin two different tests were performed: a cross-reactivity test was conducted via a binding assay by using decreasing concentrations (ranging from $\mathrm{mg}$ to $\mathrm{pg}$ ) of octanoylghrelin, des-octanoyl-ghrelin, octanoyl-ghrelin 1-5, octanoyl-ghrelin 1-14, motilin (all human, from Peninsula Laboratories) and porcine octanoyl-ghrelin (Phoenix Pharmaceuticals, Belmont, CA, USA) standards by an RIA test. Cross-reactivity was calculated according to Abraham et al. (1971). Moreover, a chromatographic separation of the molecular forms of ghrelin by reversedphase HPLC (RP-HPLC) was performed, using a HP1090 HPLC instrument (Hewlett Packard, Palo Alto, CA, USA) equipped with a Lichrospher 100 RP-18 $(5 \mu \mathrm{m})$ column (Merck, Darmstadt, Germany), and a linear gradient from 30 to $65 \%$ of acetonitrile $\left(\mathrm{CH}_{3} \mathrm{CN}\right)$ in $0 \cdot 1 \%$ trifluoroacetic acid (TFA) for $18 \mathrm{~min}$ at a flow rate of $1 \mathrm{ml} / \mathrm{min}$ at $45^{\circ} \mathrm{C}$. Retention times of the standards had been established by HPLC injections of the same peptides on a variable-wavelength HP1050 detector (Hewlett Packard) set at $l=220 \mathrm{~nm}$. After injection of extracted plasma samples on HPLC, fractions corresponding to the octanoylated (human and porcine) and des-octanoylated ghrelin, according with their retention times, were collected and assayed separately with T-4745 antiserum by RIA. Before extraction, $1 \mathrm{ml}$ plasma was diluted with an equal volume of $1 \%$ TFA and centrifuged at $4{ }^{\circ} \mathrm{C}$ for $15 \mathrm{~min}$. Acidified plasma was then loaded onto a $\mathrm{C}_{18}$ Sep-Pak-Vac, $200 \mathrm{mg} / 3$ cc cartridge (Waters Corp., Milford, MA, USA) preequilibrated with $1 \mathrm{ml}\left(\mathrm{CH}_{3} \mathrm{CN} /\right.$ water (60:40) in 1\% TFA. After three washes with $3 \mathrm{ml} 1 \%$ TFA, absorbed peptide was eluted with $2.5 \mathrm{ml} \mathrm{CH} \mathrm{CH}_{3} \mathrm{CN} /$ water (60:40) in 1\% TFA. The eluated peptide was evaporated under nitrogen and dissolved in $250 \mu \mathrm{l} 0 \cdot 1 \mathrm{M}$ PBS buffer, $\mathrm{pH} 7 \cdot 4$, to be subjected to RIA. The recovery of extraction for radioiodinated ghrelin added to plasma samples was $90 \%$. RIA was carried out using ${ }^{125}$ I-labelled human ghrelin (Peninsula). $100 \mu \mathrm{l}$ ghrelin (Peninsula) standard calibration solutions and extracted samples were incubated with antibody at $4{ }^{\circ} \mathrm{C}$ for $24 \mathrm{~h}$, then iodinated solution (14000 c.p.m./100 $\mu$ l) was added. After an overnight incubation at $4{ }^{\circ} \mathrm{C}$, bound and free ligands were separated using a goat anti-rabbit $\operatorname{IgG}$ serum and normal rabbit serum (both from Peninsula). The intra- and inter-assay coefficients of variation of the combined method of extraction and RIA were 6.0 and $9 \cdot 0 \%$ respectively.

\section{Insulin and metabolite assays}

Insulin was determined using an RIA kit (Diagnostic Products Corporation, Los Angeles, CA, USA). The sensitivity was $0.4 \mathrm{IU} / \mathrm{ml}$, the intra- and inter-assay coefficients of variations were less than 3 and 10\%, respectively. Samples were assayed for glucose with a glucose oxidase kit (Sigma Chemical Co., St Louis, MO, USA) and for NEFAs by means of a colorimetric procedure (Wako Chemicals, Richmond, VA, USA). The intra- and inter-assay coefficients of variations were 2.5 and $2 \cdot 6 \%$ for glucose and 4 and $6 \cdot 2 \%$ for NEFAs, respectively.

\section{Statistical analysis}

Statistical comparisons of effect of fasting and refeeding period on plasma ghrelin, insulin, glucose and NEFAs were performed with one-way ANOVA with Duncan post hoc analysis. A $P$ value of $<0.05$ was considered significant. Results are shown as means \pm S.E.M.

\section{Results}

\section{Experiment 1: immunohistochemistry}

In all animals studied, ghrelin-immunoreactive endocrine cells were stained brightly in the three main regions of 


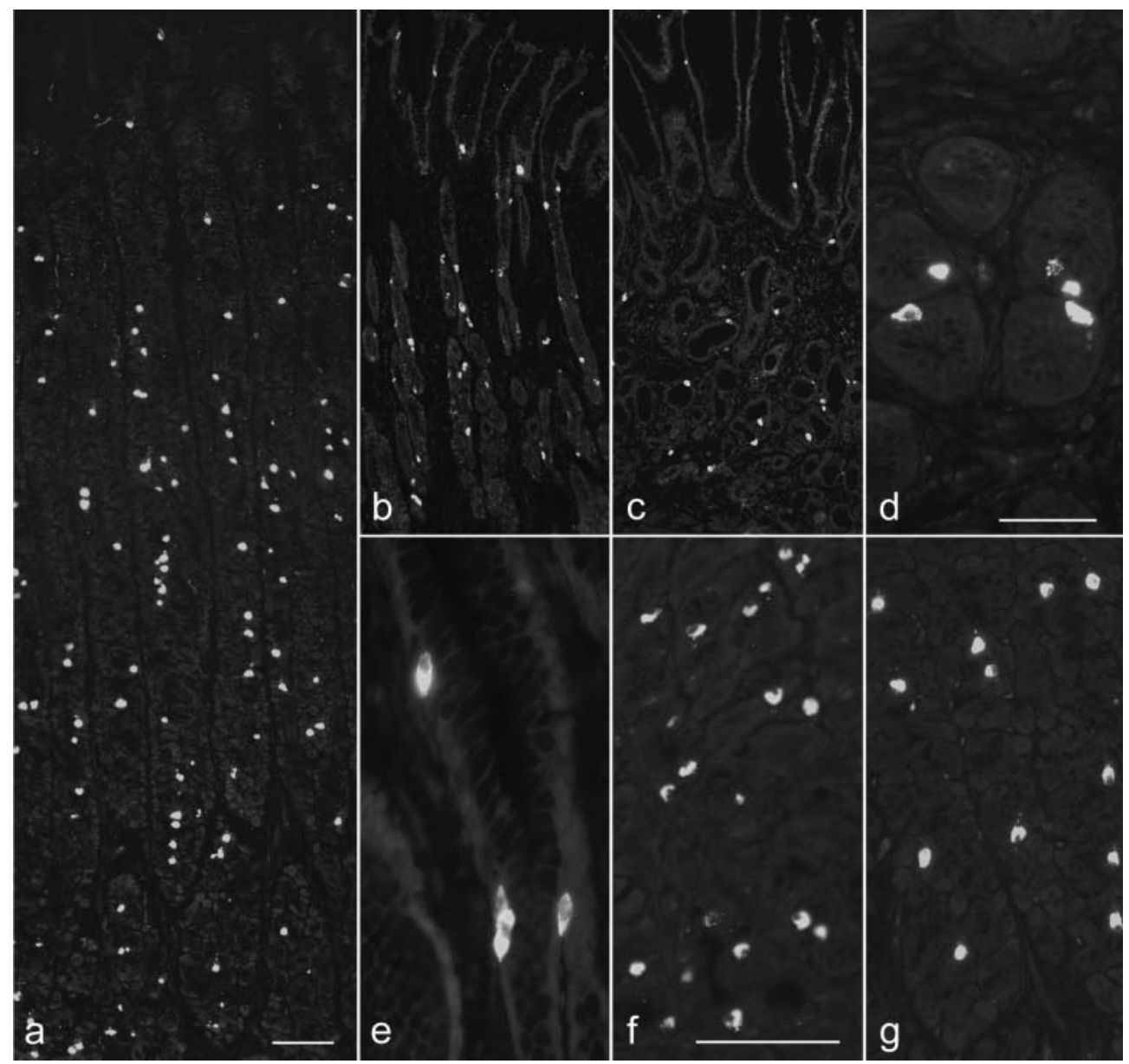

Figure 1 Immunohistochemistry. Ghrelin-immunoreactive cells were mostly localized within oxyntic glands (a), were less abundant in cardiac glands (b) and far fewer in pyloric glands (c). A smaller population of ghrelin containing cells was revealed within the epithelium lining gastric pits $(a-c, e)$ in all areas of gastric mucosa. As seen at higher magnification $(d, e)$, ghrelin labelling was confined to typical closed-type endocrine cells with no visible elongation contacting the lumen. When samples were compared across the fed and fasted groups ( $f$, fed pig; g, fasted pig) no clear-cut differences were revealed in terms of either labelled-cell numbers or immunostaining intensity. Indirect immunofluorescence; scale bars, a, $50 \mu \mathrm{m}$ (which applies to $b$ and $c$ ); $d$ and $f, 100 \mu \mathrm{m}$ (which applies to e and $g$ as well).

gastric mucosa. In pre-absorption experiments, the homologous N-terminal ghrelin ${ }_{1-10}$ synthetic peptide octanoylated at Ser-3 completely prevented staining at low concentrations $(<1 \mu \mathrm{M})$, whereas the corresponding desoctanoylated peptide was virtually ineffective $(>30 \mu \mathrm{M})$. Labelled cells were most numerous in the oxyntic mucosa, in which they were mainly distributed from the neck to the base of the oxyntic glands (approximately 10-20 cells per cross-sectioned gland, in $5 \mu \mathrm{m}$ sections; Fig. 1a), less abundant in cardiac glands (3-10 cells per gland; Fig. 1b and d) and least numerous in pyloric glands (1-3 per cross-sectioned gland; Fig. 1c). In addition, a smaller population of ghrelin-immunoreactive cells was revealed in the epithelium lining gastric pits, between the neck of the oxyntic, cardiac or pyloric glands and the luminal surface (Fig. 1a-c, e). Although small, such a population was consistently represented in the various regions of the gastric mucosa, and accounted for about 2-5\% of ghrelinimmunoreactive cells seen on sections. In all areas and locations, labelled cells showed the typical morphology of closed-type cells, lying close to the basal lamina of the glands, or of the pit epithelium, and devoid of visible elongations reaching the glands' or the gastric lumen (Fig. $1 \mathrm{~d}$ and e). When multiple sets of preparations from fed and fasted animals were compared, no clear-cut differences were revealed in terms of the frequency of labelled cells, or in their overall staining intensity. Although weakly labelled cells were more evident in a few specimens from animals of the fasted group, differences were not confirmed across other specimens from the same, as well as 

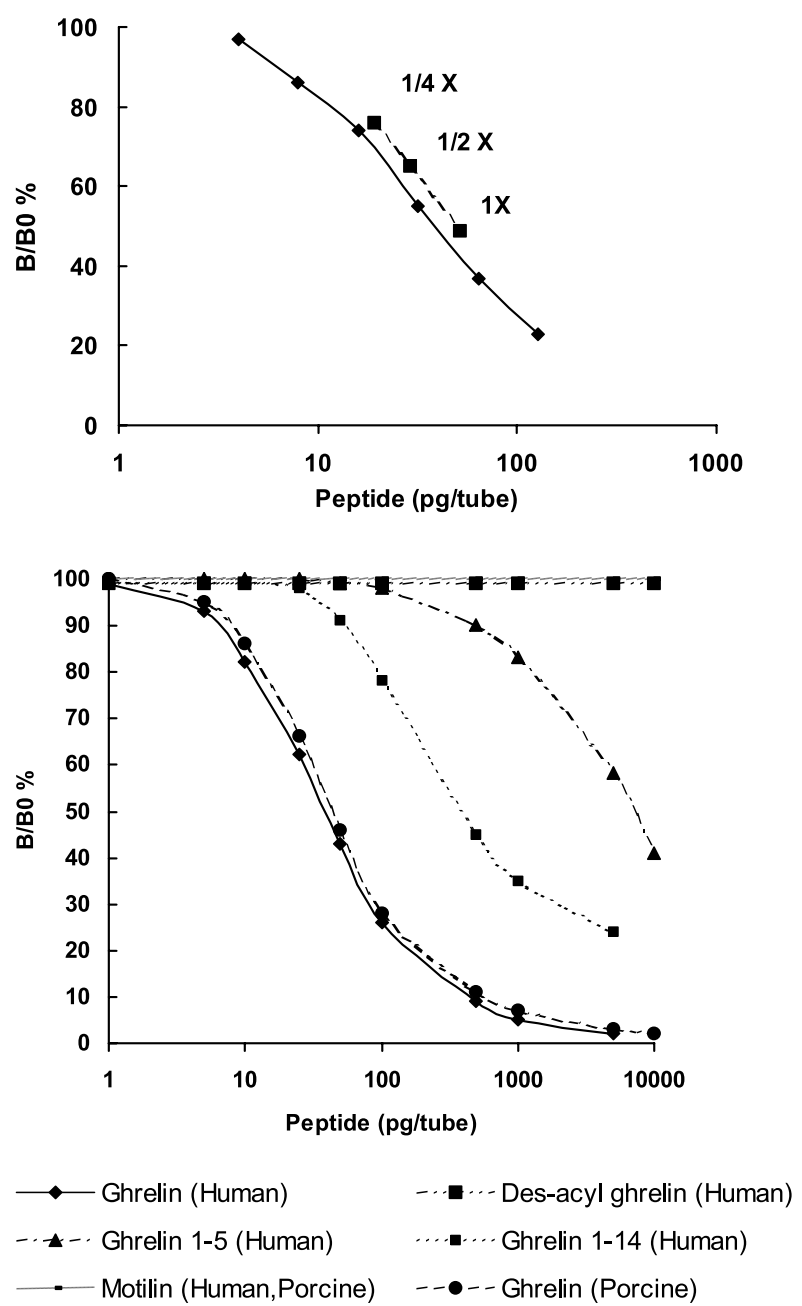

Figure 2 Ghrelin RIA curve: inhibition of radiolabelled human ghrelin binding by serial dilutions of porcine plasma extract (top panel). Cross-reactivity of antiserum: displacement of radiolabelled human ghrelin binding by serial dilutions of human and porcine peptides (bottom panel). $1 \mathrm{X}, 1 \mathrm{ml}$ porcine plasma. $y$-axis shows the $\%$ ratio of bound radiolabelled human ghrelin in presence $(\mathrm{B})$ and in absence (B0) of standard peptides.

from other, animals in the same group. Hence, an overall undistinguishable picture was revealed between the fed and fasted groups (Fig. 1f and g, respectively).

\section{Experiment 2: plasma studies}

As demonstrated by cross-reactivity test and by RPHPLC, the T-4745 antibody fully reacted with human and porcine octanoyl-ghrelin, but did not cross-react with human des-octanoyl-ghrelin (Fig. 2). Specific RIA for porcine acylated ghrelin measurement was then validated by inhibition of radiolabelled human ghrelin binding by serial dilutions of porcine plasma extract, showing a trend parallel to the RIA calibration curve (Fig. 2).
Changes in plasma ghrelin, insulin and metabolite concentrations upon fasting/refeeding are depicted in Fig. 3. Plasma ghrelin concentration was $106 \cdot 3 \pm 13.6 \mathrm{pg} / \mathrm{ml}$ (mean \pm S.E.M.) when animals were fed normally, and then increased progressively during fasting to reach levels significantly higher than in the fed state after $72 \mathrm{~h}$ $(159 \cdot 4 \pm 10 \cdot 67 \mathrm{pg} / \mathrm{ml} ; P<0 \cdot 05)$. Basal ghrelin levels were restored just $6 \mathrm{~h}$ after refeeding and remained similar to those of the prefasting period until the end of the experimental period.

During prefasting period, mean plasma insulin concentration was $33.2 \pm 6.02 \mu \mathrm{IU} / \mathrm{ml}$; the levels significantly $(P<0 \cdot 05)$ decreased after $6 \mathrm{~h}$ of fasting and continued to decrease until the end of the fasting period. After realimentation insulin levels increased rapidly, reaching values of $45 \cdot 4 \pm 13 \cdot 3 \mu \mathrm{IU} / \mathrm{ml} 6 \mathrm{~h}$ after refeeding. Glucose plasma concentrations remained unchanged throughout the experiment, except for a slightly but significantly $(P<0 \cdot 05)$ lower value seen at $72 \mathrm{~h}$. Plasma NEFA concentrations were $91 \cdot 1 \pm 20 \cdot 1 \mu \mathrm{Eq} / \mathrm{ml}$ during normal feeding, significantly increased during fasting and reached the highest concentrations at $72 \mathrm{~h}(449 \cdot 2 \pm 41 \cdot 7 \mu \mathrm{Eq} / \mathrm{ml} ; \quad P<0 \cdot 01$ compared with prefasting values). Upon refeeding, NEFA returned to basal levels within $6 \mathrm{~h}$.

\section{Discussion}

This paper reports the immunolocalization of ghrelin cells in the gastric mucosa as well as ghrelin, insulin, glucose and NEFA plasma profiles during fasting and refeeding in prepuberal gilts. In virtually all mammalian species, gastric ghrelin cells were largely found in oxyntic glands (Date et al. 2000, Tomasetto et al. 2000, Dornonville de la Cour et al. 2001, Hayashida et al. 2001, Rindi et al. 2002). Upon immunohistochemistry of the swine stomach, however, the same cells were reported to be abundant from the neck to the base of the glands in all gastric mucosal areas; that is, in cardiac, oxyntic and pyloric glands (Hayashida et al. 2001). On the basis of our study, ghrelin cells proved far more numerous in oxyntic and cardiac glands, compared with the sparser population seen in pyloric glands. Since the extent of cardiac mucosa in the pig is comparatively wide (Dyce et al. 1992), a major proportion of the gastric ghrelin cell mass may lie outside the oxyntic mucosa. In addition, the ghrelin cells we observed in the pit epithelium, though fewer than those seen within the glandular epithelium, formed a population consistently present in all regions of the gastric mucosa. Such s population has so far been scarcely noticed and even less characterized in terms of its morphology and functional response. When the fed and fasted groups were compared, acyl-ghrelin-immunostained cells did not show visible changes in frequency nor labelling intensity, in any of the main gastric mucosal areas. Hence, a limited, if any, change in intracellular ghrelin storage is suggested to occur 



Figure 3 Plasma concentrations (means \pm S.E.M.) of ghrelin, insulin, NEFAs and glucose in gilts $(n=8)$ during normal alimentation (white bars), fasting (grey bars) and refeeding (black bars). Differences (at least $P<0.05$ ) between fasting and prefasting values are indicated by *. 
during prolonged fasting. It ought to be noticed, in addition, that the usual morphology of closed-type endocrine cells was retained by all ghrelin-containing cells that we could observe.

It is well known that the biological activity of ghrelin needs the Ser-3 acylation of the molecule; moreover, the seven-amino-acid sequence at the N-terminal and the acyl modification of the third residue are well conserved between species (Kojima \& Kangawa 2005), thus suggesting the importance of using an antibody directed against the $\mathrm{N}$-terminal region of the molecule. In fact, differences between the porcine and human amino acid sequences of the acylated ghrelin are located in positions 22 and 26, in the portion of the peptide that is not recognized by an N-terminal antibody.

Ghrelin concentrations in plasma have most of the time been determined using commercial RIA kits that recognize the acylated and des-acylated forms of the hormone. As the measurement of the so-called active ghrelin may be more relevant, in this research an RIA assay was validated for porcine acylated ghrelin; since acylated ghrelin is an unstable molecule (Kanamoto et al. 2001), all preanalytical precautions had been taken to protect it against degradation to des-acyl-ghrelin (Hosoda et al. 2004).

It has been reported that ghrelin increases after fasting in both rodents (Tschop et al. 2000) and anoretic humans (Otto et al. 2001). Partially consistent with those results, we observed significant differences in ghrelin plasma concentrations only after $72 \mathrm{~h}$ of fasting; however, Salfen and colleagues (2003) in weanling pigs reported a significant ghrelin increase after $36-48 \mathrm{~h}$ of food deprivation. The differences between our and those results are possibly due to the different experimental animals (weanling pigs compared with gilts), since young animals possess fewer energy reserves and less body fat, while having higher energy requirements in connection with rapid body growth (Barb et al. 1997).

As an immediate consequence of fasting, a sharp increase of NEFAs was also observed; moreover, the drop in insulin level, seen $6 \mathrm{~h}$ after the start of fasting, may possibly be the signal for the gradual increase of ghrelin level, the highest concentrations of which coincide with the lowest glucose concentrations. However, Espelund et al. (2005) in 84-h fasting humans did not find any significant relationship between ghrelin fluctuations and either insulin or glucose. In agreement with previous studies (Flanagan et al. 2003) in humans, after refeeding insulin sharply increased while ghrelin returned to basal levels, thus demonstrating that postprandial hyperinsulinemia suppresses circulating ghrelin concentrations; these results are also in agreement with those of Broglio and colleagues (2004).

Nevertheless, evidence exists that meal-related insulin increases are not required for acute nutrient-induced lowering of circulating ghrelin (Gelling et al. 2004), even though studies in humans indicate that insulin is a determinant of the duration of meal-induced ghrelin suppression (Spanger et al. 2003, Murdolo et al. 2003). Whether insulin and/or glucose play a physiological role in regulating ghrelin secretion remains to be clarified.

Since in a previous study we observed a significant decrease in leptin plasma levels after $72 \mathrm{~h}$ of fasting and a prompt restoring after refeeding (Govoni et al. 2005), we could speculate that an inverse relationship may exist between circulating leptin and ghrelin, both hormones being involved in the central regulation of energy balance. Apart from glucose, insulin or leptin, several other parameters appear to be involved in the regulation of ghrelin, such as, for example, vagal activity: Williams and colleagues (2003) found that both atropine treatment and vagotomy block the rise of ghrelin in response to prolonged fasting.

Whereas most ghrelin is produced by and released from the stomach (Date et al. 2000, Tomasetto et al. 2000, Dornonville de la Cour et al. 2001, Hayashida et al. 2001, Rindi et al. 2002), plasma ghrelin levels are surprisingly reduced only by $65 \%$ after gastrectomy in humans (Ariyasu et al. 2001). As already mentioned, other sources might possibly contribute to ghrelin secretion (Casanueva and Dieguez 2002), thus justifying the absence of detectable changes in stomach ghrelin cells.

Studies focused on ghrelin mRNA expression or on pro-ghrelin post-translational processing might shed further light on the mechanisms underlying the adaptational response of gastric ghrelin cells. In conclusion, the present study demonstrates that starvation and refeeding influence ghrelin plasma level in prepubertal gilts, although the immunohistochemical findings do not provide evidence of any clear change in gastric ghrelin cells, probably due to a large intracellular storage of potentially releasable acyl-ghrelin.

\section{Acknowledgements}

We thank Dr M Kojima, Department of Biochemistry, National Cardiovascular Center Research Institute, Osaka, Japan, for providing the rabbit antiserum raised to the rat ghrelin ${ }_{1-11}$ peptide. Authors' contributions: N G and $G G$, blood sampling, insulin and metabolic assays; $\mathrm{MS}$ and A P, tissue sampling; RDI, UP and R P, ghrelin RIA; $\mathrm{CC}$ and $\mathrm{CB}$, immunohistochemistry; N G, C T and G-L F wrote the paper; E S and G-L F coordinated the study.

\section{Funding}

This work was supported by FIRB grants no. RBNE013 XSJ_001 to E S, nos RBNE013 XSJ_002 and RBNE01 JKLF_002 to G-L F. The authors declare that there is no conflict of interest that would prejudice the impartiality of this scientific work. 


\section{References}

Abraham GE, Swerdloff R, Tulchinsky D \& Odell WD 1971 Radioimmunoassay of plasma progesterone. Journal of Clinical Endocrinology and Metabolism 32 619-624.

Ariyasu H, Takaya K, Tagami T, Ogawa Y, Hosoda H, Akamizu T, Suda M, Koh T, Natsui K, Toyooka S et al. 2001 Stomach is a major source of circulating ghrelin, and feeding state determines plasma ghrelin-like immunoreactivity levels in humans. Journal of Clinical Endocrinology and Metabolism 86 4753-4758.

Banks WA, Tschop M, Robinson SM \& Heiman ML 2002 Extent and direction of ghrelin transport across the blood-brain barrier is determined by its unique primary structure. Journal of Pharmacology and Experimental Therapeutics 302 822-827.

Barb CR, Kraeling RR, Rampacek GB \& Dove CR 1997 Metabolic changes during the transition from the fed to the acute feed-deprived state in prepuberal and mature gilts. Journal of Animal Science 75 781-789.

Broglio F, Gottero C, Prodam F, Destefanis S, Gauna C, Me E, Riganti F, Vivenza D, Rapa A, Martina V et al. 2004 Ghrelin secretion is inhibited by glucose load and insulin-induced hypoglycaemia but unaffected by glucagon and arginine in humans. Clinical Endocrinology 61 503-509.

Casanueva FF \& Dieguez C 2002 Ghrelin: the link connecting growth with metabolism and energy homeostasis. Reviews in Endocrine and Metabolic Disorders 3 325-338.

Cocco C, Melis GV \& Ferri GL 2003 Embedding media for cryomicrotomy: an applicative reappraisal. Applied Immunohistochemistry and Molecular Morphology 11 274-280.

Date Y, Kojima M, Hosoda H, Sawaguchi A, Mondal MS, Saganuma T, Matsukura S, Kangawa K \& Nakazato M 2000 Ghrelin, a novel growth hormone-releasing acyleted peptide, is synthesized in a distinct endocrine cell type in the gastrointestinal tracts of rats and humans. Endocrinology 141 4255-4261.

Dornonville de la Cour C, Björkqvist M, Sandvik AK, Bakke I, Zhao CM, Chen D \& Håkanson R 2001 A-like cells in the rat stomach contain ghrelin and do not operate under gastrin control. Regulatory Peptides 99 141-150.

Dyce KM, Sack WO \& Wensing CJG 1992 Textbook of Veterinary Anatomy. Philadelphia: Saunders.

Espelund U, Hansen TK, Hojlund K, Beck-Nielsen H, Clausen JT, Hansen BS, Orskov H, Jorgensen JO \& Frystyk J 2005 Fasting unmasks a strong inverse association between ghrelin and cortisol in serum: studies in obese and normal weight subjects. Journal of Clinical Endocrinology and Metabolism 90 741-746.

Ferri GL, Cocco C, Melis GV \& Aste L 2002 Equipment testing and tuning: the cold-knife cryomicrotome microm HM-560. Applied Immunohistochemistry and Molecular Morphology 10 381-386.

Flanagan DE, Evans ML, Monsod TP, Rife F, Heptulla RA, Tamborlane WV \& Sherwin RS 2003 The influence of insulin on circulating ghrelin. American Journal of Physiology - Endocrinology and Metabolism 284 E313-E316.

Gelling RW, Overduin J, Morrison CD, Morton GJ, Frayo RS, Cummings DE \& Schwartz MW 2004 Effect of uncontrolled diabetes on plasma ghrelin concentrations and ghrelin-induced feeding. Endocrinology 145 4575-4582.

Govoni N, Galeati G, Castellani G \& Tamanini C 2005 Leptin concentrations in plasma and follicular fluid from prepubertal gilts as influenced by fasting, refeeding and insulin. Hormone and Metabolic Research 37 152-158.

Hayashida T, Murakami K, Mogi K, Nishihara M, Nakazato M, Mondal MS, Horii Y, Kojima M, Kangawa K \& Murakami N 2001 Ghrelin in domestic animals: distribution in stomach and its possible role. Domestic Animal Endocrinology 21 17-24.

Horvath TL, Diano S, Sotonyi P, Heiman M \& Tschop M 2001 Minireview: ghrelin and the regulation of energy balance. A hypothalamic perspective. Endocrinology 142 4163-4169.
Hosoda H, Doi K, Nagaya N, Okumura H, Nakagawa E, Enomoto M, Ono F \& Kangawa K 2004 Optimum collection and storage conditions for ghrelin measurement: octanoyl modification of ghrelin is rapidly hydrolyzed to desacyl ghrelin in blood samples. Clinical Chemistry 50 1077-1080.

Kanamoto N, Akamizu T, Hosoda H, Hataya Y, Ariyasu H \& Takaya K 2001 Substantial production of ghrelin by a human medullary thyroid carcinoma cell line. Journal of Clinical Endocrinology and Metabolism 86 4984-4990.

Kojima M \& Kangawa K 2005 Ghrelin: structure and function. Physiological Reviews 85 495-522.

Kojima M, Hosoda M, Date Y, Nakazato M, Matsuo H \& Kangawa K 1999 Ghrelin is a growth-hormone-releasing acylated peptide from stomach. Nature 402 656-660.

Masuda Y, Tanaka T, Inomata N, Ohnuma N, Tanaka S, Itoh Z, Hosoda H, Kojima M \& Kangawa K 2000 Ghrelin stimulates gastric acid secretion and motility in rats. Biochemical and Biophysical Research Communications 276 905-908.

Muccioli G, Papotti M, Locatelli V, Ghigo E \& Deghenghi R 2001 Binding of 125I-labeled ghrelin to membranes from human hypothalamus and pituitary gland. Journal of Endocrinological Investigation 24 RC7-RC9.

Murdolo G, Lucidi P, Di Loreto C, Parlanti N, De Cicco A, Fatone C, Fanelli CG, Bolli GB, Santeusanio F \& De Feo P 2003 Insulin is required for prandial ghrelin suppression in humans. Diabetes $\mathbf{5 2}$ 2923-2927.

Nakazato M, Murakami N, Date Y, Kojima M, Matsuo H, Kangawa K \& Matsukura S 2001 A role for ghrelin in the central regulation of feeding. Nature 409 194-198.

National Research Council 1988 Nutrient Requirements of Swine, 9th edn. Washington DC: National Academy Press.

Otto B, Cuntz U, Fruehauf E, Wawarta R, Folwacznyc C, Riepl RL, Heiman ML, Lehnertp P, Fichter M \& Tschop M 2001 Weight gain decreases elevated plasma ghrelin concentrations of patients with anorexia nervosa. European Journal of Endocrinology 145 R5-R9.

Peino R, Baldelli R, Rodriguez-Garcia J, Rodriguez-Segade S, Kojima M, Kangawa K, Arvat E, Ghigo E, Dieguez C \& Casanueva FF 2000 Ghrelin-induced growth hormone secretion in humans. European Journal of Endocrinology 143 R11-R14.

Rindi G, Necchi V, Savio A, Torsello A, Zoli M, Locatelli V, Raimondo F, Cocchi D \& Solcia E 2002 Characterization of gastric ghrelin cells in man and other mammals: studies in adult and fetal tissues. Histochemistry and Cell Biology 117 511-519.

Rindi G, Torsello A, Locatelli V \& Solcia E 2004 Ghrelin expression and actions: a novel peptide for an old cell type of the diffuse endocrine system. Experimental Biology and Medicine 229 1007-1016.

Salfen BE, Carroll JA \& Keisler DH 2003 Endocrine responses to short-term feed deprivation in weanling pigs. Journal of Endocrinology 178 541-551.

Salfen BE, Carroll JA, Keisler DH \& Strauch TA 2004 Effects of exogenous ghrelin on feed intake, weight gain, behavior, and endocrine responses in weanling pigs. Journal of Animal Science $\mathbf{8 2}$ 1957-1966.

Seoane LM, Tovar S, Baldelli R, Arvat E, Ghigo E, Casanueva FF \& Dieguez C 2000 Ghrelin elicits a marked stimulatory effect on GH secretion in freely-moving rats. European Journal of Endocrinology 143 R7-R9.

Spanger J, Ristow M, Otto B, Heldwein W, Tschop M, Pfeiffer AF \& Mohlig M 2003 Post-prandial decrease of human plasma ghrelin in the absence of insulin. Journal of Endocrinological Investigation $\mathbf{2 6}$ RC19-RC22.

Takaya K, Ariyasu H, Kanamoto N, Iwakura H, Yoshimoto A, Harada M, Mori K, Komatsu Y, Usui T, Shimatsu A et al. 2000 Ghrelin strongly stimulates growth hormone $(\mathrm{GH})$ release in humans. Journal of Clinical Endocrinology and Metabolism $\mathbf{8 5}$ 4908-4911. 
Tomasetto C, Karam SM, Ribieras S, Masson R, Lefebvre O, Staub A, Alexander G, Chenard M-P \& Rio M-C 2000 Identification and characterization of a novel gastric peptide hormone: the motilin-related peptide. Gastroenterology 119 395-405.

Tschop M, Smiley DL \& Helman ML 2000 Ghrelin induces adiposity in rodents. Nature 407 908-913.

Williams DL, Grill HJ, Cummings DE \& Kaplan JM 2003 Vagotomy dissociates short- and long-term controls of circulating ghrelin. Endocrinology 144 5184-5187.

Wren AM, Small CJ, Ward HL, Murphy KG, Dakin CL, Taheri S, Kennedy AR, Roberts GH, Morgan DGA, Ghatei MA \& Bloom
SR 2000 The novel hypothalamic peptide ghrelin stimulates food intake and growth hormone secretion. Endocrinology 141 $4325-4328$.

Received 9 May 2005

Accepted 21 June 2005

Made available online as an

Accepted Preprint 29 June 2005 